Revista de Literatura, História e Memória

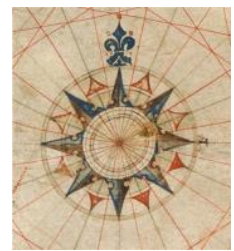

Dossiê: Manifestações de re-existência: a literatura em tempos de repressão

ISSN 1983-1498

VOL. 16 - No 27 - 2020

U N I O E S T E / CA S C A V E L - p. 61-82

\title{
O PROBLEMA DO HERÓI \\ GETÚLIO VARGAS: O TEMPO DA ESCRITA E SEUS INTERESSES NA ATUALIZAÇÃO DE PERSONAGENS HISTÓRICOS
}

The hero Getúlio Vargas's problem:

the writing time and its impacts in the recollection of historic persona

\author{
Izis Guimarães Mueller ${ }^{1}$ \\ Maria Aparecida Silva de Sousa ${ }^{2}$
}

RESUMO: O presente artigo concentra-se na análise do texto dramático Dr. Getúlio, sua vida e sua glória, escrito por Dias Gomes e Ferreira Gullar, em 1968. Buscou-se discutir as relações entre historicidade, memória, política e produção artística, evidenciando como esses elementos se articulam na construção do sentido do texto. Articulamos proposições de estudiosos da dramaturgia brasileira, como Décio de Almeida Prado, Renata Pallottini, Anatol Rosenfeld e Sandra Pascolati, para identificar, na construção do texto, o caráter atribuído às personagens; as teorizações sistematizadas por Jacques Le Goff, Maurice Halbwachs e Levi Vigotski, quanto à dimensão social da memória e da subjetividade; e a trajetória de Gomes e Gullar, com atenção aos grupos com os quais eles se engajaram. Em diálogo com as proposições de Michel Foucault, para quem a autoria de um texto está marcada pelo contexto de sua enunciação, intentamos conhecer as circunstâncias que possibilitaram a construção do caráter desta rememoração e as relações discursivas deste texto com a temporalidade em que foi produzido. Assim, notou-se que o texto analisado caracteriza a personagem como um herói e, para isso, elimina as contradições do sujeito histórico. Vargas é representado como um político nacionalista, vítima do imperialismo, desconsiderando que ele próprio negociou com esse mesmo imperialismo, além de ter feito uso de medidas autoritárias e violentas em seus governos. Concluímos que o texto apresenta uma homenagem positiva à memória do ex-presidente, como estratégia de enfrentamento à Ditadura Civil Militar, e em consonância com a tradição intelectual de esquerda que lhes era contemporânea.

PALAVRAS-CHAVE: Memória; Ditadura; Getúlio Vargas; Dias Gomes; Ferreira Gullar.

ABSTRACT: This article analysed the dramatic text Dr. Getúlio, his life and his glory, written by Dias Gomes and Ferreira Gullar, in 1968. We discussed the relation between historicity, memory, politics and artistic production, showing how those elements influence in the meaning of this text. We analysed the proposals of Brazilian dramaturges, such as Décio de Almeida Prado, Renata Pallottini, Anatol Rosenfeld and Sandra Pascolati, to identify the peculiarities attributed to the characters; the systematized theorizations of Jacques Le Goff, Maurice Halbwachs and Levi Vigotski, regarding the social dimension of memory and subjectivity; and the trajectory of Gomes and Gullar, discussing about the groups in wich they were engaged. According to the Michel Foucault's propositions, we looked for the circumstances that enabled the construction of this remembrance and also the temporality relations in wich this text was produced. We noted that the principal character was described as a national hero, and the authors eliminated the contradictions of the historical subject. Vargas were represented as a nationalist politician, an imperialism victim. The text disregard that

\footnotetext{
${ }^{1}$ Mestre em Memória, Linguagem e Sociedade (2015), especialista (2012) e licenciada (2010) em História pela Universidade Estadual do Sudoeste da Bahia; graduanda em Psicologia pela Universidade Federal de Uberlândia Minas Gerais.

2 Professora titular da Universidade Estadual do Sudoeste da Bahia no Curso de Licenciatura em História. Tem experiência na área de História do Brasil/História da Bahia, com enfoque em temáticas relacionadas à Formação

do Estado e Construção da Nação, Sertões Baianos, Conflitos políticos na Bahia Oitocentista. Integra a equipe de pesquisadores do Museu Pedagógico da UESB.
} 
Vargas negotiated with this same imperialism, in addition to having used authoritarian and violent measures in his governments. We conclude that the text presents a positive homage to the memory of the ex-president as a strategy to confront the Military Civil Dictatorship whereas both authors were contemporary with the left-wing intellectual tradition.

KEYWORDS: Memory; Dictatorship; Getúlio Vargas; Dias Gomes; Ferreira Gullar.

INTRODUÇÃO

Dentre os sujeitos que marcam a História $^{3}$ e a Memória $^{4}$ política do Brasil, o expresidente Getúlio Dorneles Vargas, é uma personagem importante e complexa, que esteve à frente do poder executivo do país por 18 anos. Destes, 15 foram ininterruptos 5 .

Suas negociações com grupos políticos antagônicos lhe renderam enquadramentos contraditórios, como as alcunhas de "pai dos pobres" e "mãe dos ricos". Embora tenha governado sob formas de governo essencialmente distintas, como o são a Democracia e a Ditadura, sua atuação política foi marcada por medidas autoritárias e centralizadoras, como foi ilustrado pela cerimônia de queima das bandeiras estaduais ${ }^{6}$, que ocorreu no Rio de Janeiro um mês após a implementação do Estado Novo ${ }^{7}$.

Além de toda propaganda produzida durante sua vida, nos anos que sucederam o seu

\footnotetext{
${ }^{3} \mathrm{O}$ conceito "História" é utilizado aqui para referir-se ao resultado de pesquisas mediadas pelos procedimentos metodológicos das diversas correntes historiográficas. Segundo o historiador Marc Bloch, História é a ciência "dos homens, no tempo" (BLOCH, 2001, p.55), uma ciência atenta as relações entre passado e presente e que serve para problematizar e compreender aspectos da duração, tais como mudança e continuidade.

${ }^{4}$ Para Jacques Le Goff, a Memória é “essencialmente mítica, deformada, anacrônica, mas constitui o vivido desta relação nunca acabada entre o presente e o passado" (LE GOFF,1990, P.22-23). Parafraseando Pierre Nora, Le Goff nos informa que a memória coletiva é "o que fica do passado no vivido dos grupos, ou o que os grupos fazem do passado" (LE GOFF,1990, p. 407). Halbwachs um importante teorizador da dimensão social da memória, sem desconsiderar os processos do indivíduo que lembra, demonstra que as lembranças são sempre coletivas, visto que, mesmo quando aparentemente sozinhos, "nunca estamos só" (HALBWACHS, 1990, p.26). $\mathrm{O}$ indivíduo que lembra, habita e está inserido em grupos de referência. Assim, a memória é um processo coletivo e inserido num contexto social. A lembrança não é um processo passivo ou natural, e tão pouco dá conta da totalidade do que se passou. Lembrar é reconstruir um acontecimento dentro de um quadro atual (presente), é um ponto de vista, que muda segundo o lugar que o indivíduo ocupa dentro de um grupo, e segundo as relações que mantém com outros grupos, outros ambientes; serve para definir e reforçar sentimentos de pertencimento e fronteiras sociais entre coletividades, referenciar identidades e manter a coesão interna por meio de uma adesão afetiva ao grupo (HALBWACHS, 1990).

${ }^{5}$ Governo Provisório (1930-1934), Governo Constitucional (1934-1937), Estado Novo (1937-1945), Governo Democrático (1950-1954).

${ }^{6}$ Nesta cerimônia, vinte e uma bandeiras estaduais foram queimadas e em seu lugar foram hasteadas vinte e uma bandeiras do Brasil. Neste exemplo de teatralização do político, Vargas deixou explícito o seu posicionamento diante das discussões acerca do federalismo e do desejo de autonomia das elites estaduais, questão que acompanha o Brasil desde a época da Independência, como quem diz que a autonomia dos Estados dali em diante estava subjugada à política nacional, cuja direção estaria centralizada em suas mãos. Imagens desta cerimonia estão disponíveis em: $<$ https://www.youtube.com/watch?v=xKoh2n1OTo4 $>$.

${ }^{7}$ Regime político ditatorial de caráter fortemente nacionalista, anticomunista e autoritário, instaurado no Brasil em 10 de novembro de 1937, através de um golpe de Estado com apoio militar, que se perpetuou até outubro de 1945.
} 
falecimento, sua existência foi rememorada ${ }^{8}$ sob diferentes enquadramentos. Jornais, revistas, eventos públicos e outros suportes discursivos contribuíram para a perpetuação desta personagem histórica na Memória nacional ${ }^{9}$.

Este artigo analisa o texto dramático Dr. Getúlio, sua vida e sua glória, escrito por Dias Gomes, em parceria com Ferreira Gullar ${ }^{10}$, em 1968, quatorze anos após o suicídio do ex-presidente Getúlio Dornelles Vargas, em plena Ditadura civil-militar ${ }^{11}$ no Brasil. No texto em questão, os autores propuseram a encenação de eventos protagonizados por Vargas, organizando-os e atribuindo-lhes sentido.

A primeira leitura que fizemos deste texto nos causou uma sensação de estranhamento: afinal, por que dois artistas socialmente reconhecidos por ter uma produção combativa e crítica à ordem social brasileira - notadamente entre as décadas de 1940 e 1970 - escolheram rememorar um ex-ditador, num ano marcado pelo acirramento da Ditadura Civil Militar no Brasil? Porque, mesmo tendo elementos para fazer uma crítica a suas ações, optaram por fazer uma rememoração que muito se aproxima de uma homenagem à memória deste expresidente?

Com o intuito de investigar estas questões, inicialmente analisamos as marcas formais, o modo como a personagem principal foi representada num texto escrito para que posteriormente fosse encenado como um espetáculo teatral. Para tanto, nos aproximamos das proposições de estudiosos da dramaturgia brasileira, como Décio de Almeida Prado, Renata Pallottini e Anatol Rosenfeld.

\footnotetext{
${ }^{8}$ A rememoração é uma atualização de eventos passados, mediada por um trabalho de enquadramento que seleciona aspectos a serem lembrados enquanto outros são esquecidos, melhor dizendo, silenciados. "O trabalho de enquadramento da memória se alimenta do material fornecido pela história. Esse material pode sem dúvida ser interpretado e combinado a um sem-número de referências associadas; guiado pela preocupação não apenas de manter as fronteiras sociais, mas também de modificá-las, esse trabalho reinterpreta incessantemente o passado em função dos combates do presente e do futuro" (POLLACK,1989, p.8).

${ }^{9}$ A Memória nacional é uma memória coletiva fortemente constituída, tida como oficial, e mediada por um esforço dominante que atua no sentido de definir o que deve ser lembrado e o que deve ser esquecido por uma coletividade (HALBWACHS, 1990). Contudo, existem também memórias subterrâneas, minoritárias e clandestinas. Michael Pollack desenvolveu um estudo importante quanto aos aspectos envolvidos nas duas operações fundantes da memória: a lembrança e o esquecimento, demonstrando que o esquecimento muitas vezes é mediado por um esforço para silenciar memórias indesejadas. Para Pollack, a Memória tem por objetivo "reforçar sentimentos de pertencimento e fronteiras sociais entre coletividades de tamanhos diferentes: partidos, sindicatos, igrejas, aldeias, regiões, clãs, famílias, nações etc. A referência ao passado serve para manter a coesão dos grupos e das instituições que compõem uma sociedade, para definir seu lugar respectivo, sua complementariedade, mas também as oposições irredutíveis" (POLLACK,1989, p.7).

${ }^{10}$ Evidências encontradas durante a pesquisa, identificaram que Dias Gomes foi o principal escritor deste texto dramático e propositor do argumento de encenação.

11 Entre as décadas de 1950 e 1980, os países da América Latina sofreram uma onda sucessiva de Golpes Militares em decorrência da política implementada pelos Estados Unidos durante a Guerra Fria, conhecida como Doutrina de Segurança Nacional, e que, com o argumento de combater o "perigo vermelho", dentro e fora do território norte-americano, destituíram governos democraticamente instituídos e implantaram governos militares por toda América (COGGIOLA, 2002). No Brasil, a Ditadura civil-militar perdurou de 1964 a 1985.
} 
Em seguida, consoantes com as proposições de Michel Foucault, questionamos a ideia de que a autoria do sentido de um texto esteja circunscrita à uma autoridade autônoma, própria dos sujeitos que o escreveram, estando antes determinada pelas condições de possibilidade do contexto de sua produção.

Nos esquivamos de uma perspectiva dualista que analisa separadamente sociedade e indivíduo, e nos aproximamos das proposições sistematizadas por de Jacques Le Goff, Maurice Halbwachs e Levi Vigotski quanto à dimensão social da memória e da subjetividade, e assim, investigamos a trajetória de Dias Gomes e Ferreira Gullar, com atenção aos grupos com os quais esses sujeitos trabalhavam, e com os quais dialogavam no contexto histórico em que o texto foi produzido; para então, acessar os projetos políticos, em disputa no ano de 1968, capazes de explicar uma abordagem positiva da memória de Getúlio Vargas por dois intelectuais brasileiros, então vinculados aos ideais marxistas e comunistas.

O Materialismo Histórico, a compreensão de que toda ação humana está materialmente ancorada e historicamente circunscrita num quadro de relações sociais, é a perspectiva analítica aqui empregada. Nesta perspectiva, o texto analisado é uma produção discursiva associada a interesses, afetos, e a um posicionamento na ordem social.

Intentamos conhecer as circunstâncias que possibilitaram a construção do caráter desta rememoração e as relações discursivas deste texto com a temporalidade em que foi produzido.

\section{O TEXTO E SUAS MARCAS FORMAIS}

Desde o título, observamos elementos de uma rememoração positiva. Nota-se que "glória" é uma palavra que significa honra, homenagem, fama e refere-se também ao círculo luminoso, que se representa em volta da cabeça dos santos, como marca de sua diferenciação diante dos homens comuns.

Em sua totalidade, o texto tem um caráter fortemente nacionalista e anti-imperialista, trazemos como exemplo o trecho abaixo, que rememora a campanha em favor da nacionalização da exploração do petróleo:

As aves saltam dos pedestais e saem correndo atrás do embaixador. Dois negros entram, dançando também, e levam o sofá com Getúlio sentado nele. A bateria muda de ritmo: marcha batida. Homens e Mulheres entram, em massa compacta, portando cartazes que dizem: "O petróleo é nosso, monopólio estatal", "um povo que cede o seu petróleo aliena a sua soberania", etc. Povo: (ritmado) Não é seu nem vosso, O petróleo é nosso (GOMES; GULLAR, 1968, p. 41). 
Com este fragmento, fica evidenciado também o quanto o texto é rico em recursos de teatralização, que indicam um repertório de movimentos, sons e imagens que deverão compor a visualidade cênica, quando o texto for transposto das páginas para o palco, mas que também permitem ao leitor imaginar a priori tal transposição.

O termo teatralidade refere-se a "tudo que, no texto, contribui para a construção de sua visualidade, todos os signos que se configuram iconicamente (gesto, figurino, marcação de cena, objetos de cena, entonação) são matrizes de imagens, são apelos à construção visual do leitor" (PASCOLATI, 2008, p.2).

Dentre tais recursos, identificamos a presença de uma dança tradicional, o samba, e o uso de carros alegóricos para ilustrar as situações representadas; o figurino é indicado como uma estratégia discursiva, existindo, por exemplo, a sugestão de que o embaixador dos Estados Unidos seja escoltado por atores fantasiados como aves de rapina, o que funciona como um jogo metafórico para demonstrar a relação que a potência imperialista pretendia manter com o Brasil; a musicalidade está presente em todo o texto, primeiro nas falas das próprias personagens, que muitas vezes são ordenadas em verso, segundo pelas entradas do coro, que canta o samba enredo e, finalmente, pela indicação da presença no palco de uma bateria de escola de samba, que irá executar a trilha sonora do espetáculo, intensificando a dramaticidade do texto, comentando as ações e ilustrando as situações.

Tanto o trecho anteriormente citado, como o que segue abaixo, nos trazem uma noção da espetacularidade visual enunciada:

A Bateria volta a tocar. Embaixador veste o manto, enquanto entra um Garoto puxando um carrinho de brinquedo. No carrinho está escrito Capital. Em seguida entram dois negros fortes, musculosos, de corpo nu, vestido como Escravos, atrelados a uma carreta cheias de enormes barras de ouro. Os negros arrastam a carreta com imenso esforço. Na carreta está escrito Lucros do Capital. Embaixador ao sair esbarra em um dos Escravos (GOMES; GULLAR, 1968, p. 40).

Ao longo do texto, identificamos o uso de uma série de recursos metalinguísticos que rompem a ilusão teatral e que, diferente de um espetáculo com aspiração naturalista, lembra constantemente o público que o que está sendo mostrado não é a vida real tal como ela é, ou tenha sido, mas um jogo cênico, uma construção intencional previamente elaborada. Identificamos, por exemplo, o uso de placas e cartazes, a fim de comentar as ações e informar seu pano de fundo social; a presença de narradores que antecipam as ações que irão acontecer 
e justificam o seu inacabamento, e a quebra da quarta parede, com os atores se dirigindo diretamente para o público.

Pascoali (2008), observa que:

\begin{abstract}
O metateatro é um dos recursos encontrados pela dramaturgia moderna para reteatralizar o palco no século XX. Muitos signos teatrais - cenário, personagens, palavra, gestos, som - são trabalhados de modo a não permitir que o espectador mergulhe na ilusão, lembrando-o constantemente de estar no teatro e que tudo que se desenrola no palco é previamente estabelecido, calculado e programado. Assim, a dramaturgia moderna caminha para uma consciência aguda de seus anseios e limites, questionando formas dramáticas e técnicas de representação" (PASCOLATI, 2008, p. 8).
\end{abstract}

Interessante observar que a escolha de Gomes e Gullar em construir um texto com elementos dramatúrgicos auto reflexivos, com a existência de elementos que comentam a própria construção das cenas e suas características, evidenciando que aquilo que está sendo apresentado se trata de uma elaboração discursiva possível, mas não a única, e jamais uma cópia do real, e sim uma representação, aproxima seu texto das proposições do teatro épico brechtiano.

O dramaturgo Bertolt Brecht ressaltou a responsabilidade política e pedagógica do teatro como ferramenta de crítica à sociedade. Com um posicionamento marxista e antiilusionista, Brecht defendeu que o teatro deve despertar a razão do público, o fazendo lembrar que a realidade é mutável e que a sociedade está em constante transformação.(BRECHT, 1967).

Para produzir tal efeito e proporcionar ao público teatral meios que ativem sua reflexão crítica, Brecht lançou mão de recursos teatrais anti-ilusionistas, para que o público, ao invés de se identificar com as situações encenadas, se distancie, e assim as analise criticamente. Este efeito de distanciamento em relação ao que é encenado é produzido através de recursos metateatrais, que reforçam a teatralidade do espetáculo cênico.

Sobre a forma do teatro épico, Brecht declarou que:

Não se permitia de modo algum ao espectador entregar-se sem qualquer crítica (e sem qualquer consequência prática) aos acontecimentos por meio da identificação com os personagens dramáticos. A representação submetia os assuntos e ocorrências a um processo de distanciamento. Trata-se do distanciamento, que é necessário para que se possa compreender. Em relação a tudo que é evidente por si mesmo se renincia a compreensão. O natural tinha de ser acrescido do elemento extraordinário. Somente assim é que as leis de causa e efeito poderiam aparecer em evidência. Era preciso que a atuação dos homens fosse tal e pudesse, ao mesmo tempo, ser outra (BRECHT, 1967, p. 96). 
Observamos que o recurso metateatral, anti-ilusionista e de distanciamento, mais marcante existente no texto Dr. Getúlio, sua vida e sua glória é a opção formal de sobrepor dois planos de enunciação, onde os atores se desdobram na representação de várias personagens, fazendo com que um plano interrompa o outro na medida em que vão se esclarecendo mutuamente.

A dramaturgia do texto é tecida no entrelaçamento de duas temporalidades, correlacionando o período histórico rememorado com os ensaios de uma escola de samba. No primeiro plano, se desenrolam os conflitos internos e as brigas pela presidência da escola: o ex-financiador e bicheiro, Tucão, não aceita o resultado das eleições que levaram seu opositor, Simpatia, à presidência, e conspira para destituí-lo do cargo e assumir sua posição, ao mesmo tempo em que a escola ensaia para o desfile de carnaval.

No segundo plano, desenvolve-se a história narrada pelo samba enredo: algumas ações de Getúlio Vargas na presidência do Brasil, a instabilidade e as disputas pelo poder presidencial, que marcaram os últimos anos do governo até o suicídio do então presidente. Neste plano, o conflito central ocorre entre as vontades e objetivos de Getúlio Vargas, representado como defensor da nação, versus Carlos Lacerda e o imperialismo dos Estados Unidos, empenhados na deposição do presidente ${ }^{12}$.

As rubricas indicam que os atores devem se desdobrar na representação das personagens dos dois planos narrativos, de modo que, o mesmo ator ou grupo de atores, deve assumir a personagem correspondente de acordo a temporalidade do plano de encenação. Assim, um ator representará Getúlio e, também, Simpatia. Um outro ator representará as personagens Tucão e Lacerda, e outros paralelismos são estabelecidos com as demais personagens do espetáculo.

Essa correlação faz com que os planos narrativos denotem um ao outro e evidenciem a caracterização atribuída a cada personagem. Por exemplo, a insatisfação de Tucão em não aceitar a presidência de Simpatia, suas ações e posicionamentos, refletem no caráter dos estratagemas de Lacerda, enquanto que, o carisma de Simpatia e os seus esforços para que a escola consiga desfilar no carnaval, refletem sobre a caracterização da personagem Getúlio. A correlação entre essas duas personagens e suas personalidades chega ao ápice quando a morte de Simpatia coincide com a morte Getúlio, e o caráter das circunstâncias que a precederam.

\footnotetext{
12 Carlos Frederico Werneck de Lacerda (1914-1977), foi um jornalista e político brasileiro, vinculado à União Democrática Nacional (UDN). Opositor de Vargas, se aliou aos militares e partidos opositores do presidente, fazendo uso de seu jornal, Tribuna de Imprensa, em intensa campanha contra o governo Vargas (NETO, 2014. 464p.).
} 
Note-se que, no teatro, "as personagens constituem praticamente a totalidade da obra: nada existe a não ser através delas", que funcionam como um meio pelo qual o autor exprime seus posicionamentos (PRADO, 2007,84). O modo como cada uma das personagens age durante os conflitos demarca o caráter atribuído a elas na trama.

A dramaturga Renata Pallottini observa que a personagem é um ser, cujo caráter é delineado por palavras e gestos, informações estas que fazem com que saibamos quem ela é e quais são os seus objetivos. Assim, caracteriza-se a personagem pelo que ela faz em determinada situação, onde sua vontade e objetivo entram em conflito com a vontade e o objetivo de outra personagem que lhe é antagônica (PALLOTTINI, 1988; 1989).

No trecho a seguir, observamos a personagem antagonista, Lacerda, apresentar os estratagemas para atingir seu objetivo:

AUTOR: Como se depõe um presidente.

LACERDA: É simples:

Em primeiro lugar,

É preciso levantar

A bandeira moralista:

Mostrar que o governo é corrupto,

Composto de chantagistas,

De ladrões

De rufiões,

Cafetões e vigaristas

[...]

Isto é muito importante.

Com a bandeira moralista,

Ganha-se então por inteiro

A famosa classe média,

Que sonha em ter em virtudes

$\mathrm{O}$ que lhe falta em dinheiro.

[...]

Em segundo lugar,

Lançar mão sem hesitar

Da ameaça comunista

[...]

Diante disso, o burguês

Fica logo apavorado

E sem contar até três

Se passa pro nosso lado.

[...]

E, finalmente,

Para se depor um presidente,

Manda a boa técnica

Que, em terceiro lugar

Se acuse o Governo

De pretender dar o golpe

Que nós pretendemos dar.

(GOMES; GULLAR, 1968, p. 55-58). 
Com esta fala, que parece bastante atual, o texto demarca o caráter da personagem antagônica como o de um golpista, alguém que conspira e manipula a opinião pública com a intenção de derrubar, de modo desonesto, um governo legalmente instituído. A personagem Lacerda fala abertamente sobre suas estratégias para depor o então presidente, o que, em contrapartida, também enuncia que a personagem protagonista, Getúlio, foi vítima de uma conspiração.

Se as falas do antagonista o caracterizaram como um golpista, o protagonista, por outro lado, é representado como um herói. Observe um diálogo entre Getúlio e sua filha Alzira:

\begin{abstract}
ALZIRA - Quero meu pai vivo em São Borja, não quero ele morto no Catete. [...] Estou dizendo o que sinto. O senhor sabe que eu não queria que senhor voltasse ao Governo.

GETÚLIO - E tu sabes também que eu fiz tudo para que isso não acontecesse. Só aceitei mesmo quando vi que, se não voltasse, eles iam destruir o que ainda resta da minha obra. A Legislação Trabalhista, a siderurgia e tudo o mais. Voltei para defender isso. Mas não queria. Como não quis ser chefe da revolução de [19]30. Como não quis ser Ditador em [19]37. Sou como aquele sujeito que salta do mar, salva uma criança de morrer afogada e vira herói. Mas ninguém sabe que ele foi empurrado. Eu sempre fui empurrado. [...] Mas quando me empurram, nado como se tivesse mergulhado por minha própria vontade. Aí é que está a habilidade de um estadista: em se deixar empurrar pela História. E ceder aqui, barganhar ali, mas ver sempre para onde a História vai e ir com ela [...] (GOMES; GULLAR,1968, p. 30 e 31).
\end{abstract}

Nesta cena, a personagem Getúlio aparece como alguém que vê a política como uma missão. Os interesses do país e do povo estão acima dos seus próprios, ele segue seus impulsos (salta para salvar a criança), porque as condições externas assim exigem dele essa atitude heroica, e não porque ele queira ser um herói, é um sujeito destituído de tal ambição, contudo, não foge aos desafios que lhe são colocados; a tarefa não foi por ele premeditada, mas, agir assim é próprio de sua personalidade. Tal fala, corrobora com a manutenção de uma visão mítica sobre a personagem histórica, que inspira a construção do texto.

O ex-presidente Vargas é rememorado na trama como um sujeito extraordinário, e que defende os interesses do povo, mesmo que isso signifique sua própria ruína. Num outro trecho, a personagem protagonista refere-se ao povo como portador de uma ingenuidade, o que reforça a imagem do então presidente como o pai protetor dos pobres: "GETÚLIO -... há muita gente contra nós... Até mesmo o povo... que não entende que está contra si mesmo" (GOMES; GULLAR, 1968, p. 104). 
Analisando o texto, observamos a existência de elementos, na caracterização da personagem principal e na organização da dramaturgia do texto, similares às proposições do herói trágico aristotélico. Porém, a referência aristotélica foi atualiza numa fórmula renovada e presente. Dias Gomes e Ferreira Gullar se apropriaram desta referência e a reinventaram de acordo ao contexto em que estavam inseridos.

Segundo Aristóteles, a tragédia é

imitação de uma ação de caráter elevado, completa e de certa extensão, em linguagem ornamentada e com as várias espécies de ornamento distribuídas pelas diversas partes [do drama], [imitação esta que se efetua] não por narrativa, mas mediante atores, e que, suscitando o terror e a piedade, tem por efeito a purificação das emoções [catarse] (poética VI, 27, 1449b, 24).

Ora, o objeto de imitação de caráter elevado apresentado desde o título do texto é, pois, a "vida e a glória" do "Dr. Getúlio"; o herói trágico, abatido por uma catástrofe capaz de comover quem a testemunhe. A personagem que se mostra movida pelo desejo de governar em benefício do povo e da nação, é traída e, vítima de uma conspiração, se vê na iminência de perder a posição que ocupa.

Esta peripécia, "mutação dos sucessos no contrário", mudança de sorte que altera subitamente a situação (ARISTÓTELES, Poética XI, 60, 1452a, 22), ocorre com a encenação da notícia de que um atentado contra a personagem Lacerda (ferida com um tiro no pé), resultou na morte do major-aviador que fazia sua segurança, mas que ironicamente estava desarmado, e é morto com dois tiros, um nas costas e outro no peito ${ }^{13}$.

No texto de Gomes e Gullar, a personagem Getúlio mostra-se surpresa com o atentado e desconhece os mandantes do crime. Com a intenção de esclarecer as circunstâncias e provar sua inocência, concorda que uma investigação seja feita, sem poupar sequer as pessoas mais próximas e de sua confiança. É com grande desapontamento que a protagonista vai tomando ciência de que Gregório - chefe de sua guarda pessoal, seu homem de confiança - tinha realizado transações irregulares que envolviam seu próprio filho, Manuel Vargas, o que poderia ser um indício de suborno, fato levado em conta pelo inquérito instaurado.

A condenação de Gregório refletiu diretamente na imagem de Getúlio. Numa cena em

\footnotetext{
${ }^{13} \mathrm{Na}$ realidade empírica, um evento similar ganhou importância histórica e foi tratado com o argumento que precipitou uma crise política que abalou definitivamente o último Governo Vargas, fomentando uma campanha por sua renúncia que teve repercussões no Congresso, na imprensa e nas ruas. O jornalista Carlos Lacerda acusou Vargas de ser o único mandante do crime, o que desmoralizou o presidente diante da opinião pública e o fez perder o apoio das forças armadas, notadamente da Aeronáutica, que já havia se posicionado favorável à eleição de Lacerda para deputado federal (MORAIS, 2006; NETO, 2014).
} 
que o então presidente se reúne com seus Ministros, para examinar a situação política, fica evidente que os chefes militares preferem a renúncia do então presidente a um novo Golpe político.

Após a encenação destes acontecimentos desenrolam-se as cenas finais. Getúlio troca as últimas palavras com a filha: "Tu achas justo lançar o país numa guerra civil por conta de um velho de sessenta anos?" (GOMES; GULLAR, 1968, p. 101). “[...] é inútil minha filha, já tomei a decisão que devia e ninguém vai alterar os meus planos. Como disseste a pouco, tudo vai acabar bem... no fim..." (GOMES; GULLAR, 1968, p. 105). Quando finalmente fica sozinho, o presidente tira do bolso uma cópia da carta testamento, desdobra e a lê, ao passo em que se ouve sua voz pelo alto-falante. Entra em cena uma ampliação da carta testamento, em cima de uma carreta tal qual uma alegoria de carnaval. Ouvem-se gritos, vozes e o barulho de um tiro. "Mataram Simpatia!", "Mataram Getúlio! ”. Os membros da escola invadem a cena e todos se voltam contra Tucão e as Aves de Rapina, que fogem apavorados. O surdo passa a soar em ritmo lento e os participantes da escola cantam o samba enredo em tom lamentoso até que a cama onde estava o corpo de Getúlio desaparece de cena. De súbito há uma mudança no ritmo da bateria que explode numa batucada alucinante. "Os passistas dançam fervorosamente como tomados de loucura" (GOMES; GULLAR, 1968, p. 107-108).

Segundo a poética aristotélica, a catástrofe ${ }^{14}$ da personagem trágica inicia quando ela descobre o seu destino e segue-o até o desenlace. Em Dr. Getúlio, sua vida e sua glória, a catástrofe é a própria morte da personagem principal, ato radical e último que libera a protagonista de toda culpa e desconfiança do povo. O então presidente comete suicídio e, ao fazer isso, provoca uma grande comoção popular que, tal qual uma catarse, purifica o entendimento da população a respeito da trama política, restituindo o apoio do povo a sua causa.

Na criação artística, a forma escolhida para se comunicar o que se quer dizer também é conteúdo de enunciação, e por isso não pode passar despercebida a escolha formal de rememorar Getúlio Vargas através da representação dos bastidores de uma escola de samba, como um recurso metalinguístico que se apropria de uma estrutura narrativa característica da tradição cultural popular brasileira (o enredo das escolas de samba) para falar de uma personagem da História nacional (Getúlio Vargas).

O sociólogo Marcelo Ridenti (2010), identifica que na produção artística da década de 1960, o samba, a batucada e o carnaval são usados como metáforas para anunciar um novo

\footnotetext{
14“'Segundo Aristóteles a "catástrofe é uma ação perniciosa e dolorosa, como os são as mortes em cena, as dores veementes, os ferimentos e mais casos semelhantes" (poética VI,1452b, 3-64).
} 
porvir, uma alteração da ordem que traria o povo como protagonista de sua própria história e da vida política pública, inaugurando uma nova ordem social mais justa, e livre da repressão política. Como exemplo disso podemos citar as canções: Ensaio geral de Gilberto Gil, escrita em $1966^{15}$, e Olê, Olá de Chico Buarque, escrita em $1965^{16}$, produções estas contemporâneas à escrita de Dr. Getúlio, sua vida e sua glória.

No que se refere ao teatro, nas décadas de 1960 a 1970, o teatro musical foi organizado para "responder de modo crítico ao regime militar instaurado em 1964" (PARANHOS, 2016, p. 69). Podemos observar isso em espetáculos, como Arena canta Zumbi, Arena canta Tiradentes, e o show opinião, todos com grande projeção em seu contexto de encenação e que até hoje marcam a história do teatro brasileiro.

Nota-se que a primeira montagem teatral do texto Dr. Getúlio, sua vida e sua glória foi realizada pelo Opinião, um grupo de teatro que "focalizava suas ações no teatro de protesto, de resistência, e também se caracterizava por ser um centro de estudos e de difusão da dramaturgia nacional e popular" (PARANHOS, 2012, p. 147). Apropriando-se de uma interpretação do que é nacional e do que é popular, muito próxima a do Partido Comunista Brasileiro (PCB), o grupo empenhou-se em fazer uma arte engajada na crítica à Ditadura Civil-Militar, na defesa da democracia, e na análise crítica da realidade brasileira. Em sua atuação, a encenação de musicais configurou-se como ato de resistência à Ditadura CivilMilitar. Dias Gomes enxergava no trabalho deste grupo uma ação política combativa, segundo ele: "A plateia que ia assistir ao show Opinião, por exemplo, saia com a sensação de ter participado de um ato contra o Governo" (GOMES, 1991, p. 609).

Os elementos formais apresentados demonstram que Dr. Getúlio, sua vida e sua glória é uma rememoração positiva do ex-presidente Vargas, num texto cuja estética evidencia um engajamento político anti-imperialista e nacionalista, através da apropriação de elementos da tragédia aristotélica e de recursos de teatralização brechtianos, atualizados e abrasileirados na aproximação com o enredo de uma escola de samba e na representação de acontecimentos da História política nacional.

\section{PRODUÇÃO ARTÍSTICA E MEMÓRIA SOCIAL}

É sempre delicado analisar a relação entre arte e realidade, bem como, entre o ocorrido

\footnotetext{
15 “tá na hora vamos lá/ carnaval é pra valer/ Nossa turma é da verdade/ e a verdade vai vencer."

16 "não chore ainda não/ que eu tenho a impressão/ que o samba vem aí/ e um samba tão imenso/ que eu as vezes penso/ que o próprio tempo/ vai parar pra ouvir".
} 
e suas representações. Uma única teoria não é capaz de abarcar as características e os condicionantes de todos os modos e métodos de criação artística que tenham como tema elementos históricos.

Contudo, analisando especificamente o texto aqui apresentado, e a produção artística de seus escritores, é possível fazer um recorte de observação: estamos analisando uma produção do Teatro Moderno Brasileiro. Um modo de fazer e pensar Teatro que "deslanchou" entre as décadas de 1940 e 1970, em resposta às influências do acirramento do conflito entre capitalismo e comunismo, bem como da militância antifascista (PRADO, 2003).

Esta argumentação está em consonância com as observações do historiador Eric Hobsbawm, ao apontar que, a guerra, personagem central da História do século XX, e a reverberação da Revolução Russa, marcaram a politização das artes e o posicionamento dos artistas a que chamamos modernistas, os fazendo assumir um compromisso político com as massas, "sua inspiração era "ir ao povo" pintar um quadro realista de seus sofrimentos e ajudá-lo a revoltar-se" (1995, p. 190).

Analisando uma produção do Teatro Moderno Brasileiro, inserida no contexto de uma Ditadura civil-militar, período histórico que tem dentre suas marcas o autoritarismo, a repressão e a censura como marcas de uma política autoritária; inicialmente pareceu-nos incoerente uma rememoração positiva de Vargas dentro deste contexto. Contudo, nossa investigação revelou uma explicação diferente.

Nota-se que, em outro momento histórico, no ano de 1998, em sua autobiografia, ao descrever sua relação com os governos Vargas, Dias Gomes, principal autor do texto, afirmou que foi perseguido pela Ditadura varguista e em diversos momentos foi impedido de trabalhar, pois seu nome constava na lista do DOPS (Departamento de Ordem Política e Social) como sendo um agente subversivo. Neste relato, Gomes conta que, no ano de 1944, ainda trabalhava na rádio Pan-Americana quando dois policias, informados de que ali atuavam militantes comunistas, entraram no estúdio em que estava. Incomodado, Dias Gomes teria aproveitado os microfones abertos para fazer uma crítica contra a Ditadura do Estado Novo, quando então os policiais tentaram capturá-lo:

Agora mesmo, senhores ouvintes, este estúdio acaba de ser invadido por dois cães policiais, dois agentes da ditadura. Eu não admito isso e, em sinal de protesto, vou tirar este programa do ar [...]. Estou sendo espancado por dois agentes da ditadura! Gritei. - Talvez seja morto por eles, como outros já o foram pela polícia de Felinto Muller! Essa é a ditadura fascista de Vargas, tão fascista como as de Mussolini e Hitler (GOMES, 1998, p. 97 e 98). 
Comparando o enquadramento dado à rememoração do ex-presidente nesta narrativa autobiográfica (1998), com o enquadramento construído pelo texto dramático (1968), temos duas imagens de caráter distintos de uma mesma personagem histórica.

Maurice Halbwachs, um estudioso da Memória social, assinalou que:

Em realidade, nunca a imagem de um falecido se imobiliza. À medida em que recua no passado, muda, porque algumas impressões se apagam e outras se sobressaem, segundo o ponto de vista de onde a encaramos, isto é, segundo as condições novas de onde ela se encontra quando voltamos para ela (1990, p. 74).

No que se refere a Getúlio Vargas, esta afirmação mostra-se bastante apropriada. Jacques Le Goff (1990), em seu estudo sobre as relações que os homens em sociedade estabelecem com o passado, e sobre os modos como o passado é reatualizado, é incisivo ao destacar a importância do tempo presente nesta reatualização. O presente é entendido como o lugar do devir, do útil e do interesse, o aqui e agora que recupera o passado quando lhe é útil e necessário, de modo que rememoramos sempre o que nos interessa e ressignificamos o acontecido com base em nosso contexto atual.

A arte, ainda que goze de certa liberdade quando comparada a outras metodologias de representação do real, não é um discurso gratuito e deslocado do momento presente em que se insere. Estando ou não consciente disso, o artista e sua produção estão socialmente posicionados. O psicólogo Levi Vigotski, enfatiza que:

A arte é o social em nós, e se o seu efeito se processa em um indivíduo isolado, isto não significa, de maneira nenhuma, que suas raízes e essência sejam individuais. [...] O social existe até onde há apenas um homem e as suas emoções. [...] A refundição das emoções fora de nós realiza-se por força de um sentimento social que foi objetivado, levado para fora de nós, materializado e fixado nos objetos externos da arte, que se tornaram instrumento da sociedade (VIGOTSKI,1999, p. 315).

A ideia do indivíduo como autor de um texto, como o único responsável pela criação e pelo sentido de uma produção discursiva torna-se cada vez menos sustentável. Michel Foucault $(1996,2006)$, evidencia que numa sociedade como a nossa, que tem como pilar a prática discursiva, é preciso que estejamos sempre atentos ao fato de que, os discursos não são construções aleatórias e livres, apenas regulados pelas regras internas da linguagem. São antes práticas interessadas e coagidas pela vontade de verdade e pela vontade de poder; constituindo-se como um jogo de signos que pode tanto estar em consonância com a ordem 
social como se opor a ela, trazendo em si as marcas de seu posicionamento.

Foucault enfatiza que as produções discursivas são fabricadas no interior das relações sociais, enquanto produtos destas relações. Sem negar a existência de um indivíduo, de um humano que escreve. Este sujeito é visto como um ser coletivo de dimensão histórica e cultural, cuja ação e comportamento são socialmente estruturados e socialmente significativos. Nesta perspectiva, a autoria, a autoridade que determina o sentido do texto, assenta-se antes no contexto em que ele é produzido e pelo qual circula do que na vontade criativa do sujeito que o escreveu.

O que o escritor faz é se apropriar e reatualizar discursividades já existentes, dizendo de uma forma nova o que já foi dito, a partir da posição que ocupa na sociedade, das práticas discursivas com as quais dialoga e das condições de possibilidade presentes (FOUCAULT, 1996).

\section{OS SUJEITOS QUE ESCREVERAM E OS GRUPOS EM QUE ESTAVAM ENGAJADOS}

Dias Gomes e Ferreira Gullar não eram historiadores e, ao recuperar acontecimentos da História do país e os organizar numa narrativa dramática, não tinham as preocupações metodológicas e os compromissos éticos que acompanham o trabalho de um profissional da História, mas certamente tinham outros compromissos próprios à atividade que exerciam enquanto artistas, prática discursiva também atuante no reforço de uma Memória nacional ou na confrontação de uma memória que se queira hegemônica.

Ferreira Gullar (1930-2016) fez parte do núcleo permanente do Grupo Opinião. Em seus escritos, elaborados nas décadas de 1960 a 1970, defendeu o engajamento dos artistas ao lado dos interesses populares e o desenvolvimento etapista da nação, compreendendo o subdesenvolvimento do Brasil como uma etapa a ser superada. Na década de 1960, publicou dois importantes textos teóricos: Cultura posta em questão (1965) e Vanguarda e subdesenvolvimento (1969), nos quais realizou um estudo crítico sobre a produção artística brasileira, discutindo a problemática dos conceitos de "homem brasileiro" e de "cultura brasileira", combateu o formalismo, "a arte pela arte", e defendeu o uso de uma linguagem acessível a todos, e propôs uma aproximação entre o marxismo e o nacionalismo (MOTA, 1977, p. 229-239).

Dias Gomes (1922-1999) atuou em diversos segmentos da indústria midiática brasileira, entre as décadas de 1940 e 1990: rádio, literatura, teatro, televisão e cinema, sendo censurado pela repressão de duas ditaduras (Ditadura do Estado Novo e Ditadura civil- 
militar $)^{17}$. Nas décadas de 1940 e 1950 atuou no rádio, quando este já tinha uma programação voltada para as classes médias e populares e, na década de 1960, passou a integrar os quadros de trabalho da Rede Globo, num momento em que a televisão se consolidava como o mais importante canal de comunicação de massa do país (JUNIOR, 2001). Seu nome e seu trabalho percorreram parte importante da História da indústria cultural brasileira, bem como da História da dramaturgia nacional (SACRAMENTO, 2012).

Dentre os grupos que Dias Gomes e Ferreira Gullar participaram, é preciso mencionar a filiação de ambos ao Partido Comunista Brasileiro. Estes artistas vivenciaram distintos momentos do partido em relação aos seus intelectuais e às suas diretrizes culturais, bem como a posicionamentos distintos do $\mathrm{PCB}$ em relação a $\operatorname{Vargas}^{18}$. Dias Gomes chegou a ser dirigente do comitê cultural do PCB, no Rio de Janeiro, e atuou no Comando dos Trabalhadores Intelectuais (CTI), organização que propunha formar uma frente única, democrática e nacionalista pela melhoria das estruturas da sociedade brasileira (GOMES, 1998).

Outro grupo defensor da produção cultural como elemento de conscientização política e de transformação social, ao qual Gomes e Gullar integraram, foi o conselho de redação da Revista Civilização Brasileira (RCB). A RCB posicionou-se criticamente contrária à Ditadura, instalada com o Golpe de 1964. Segundo Carlos Guilherme Mota (1977), a Revista Civilização Brasileira foi um espaço que abrigou textos de artistas e outros intelectuais que pensavam criticamente a arte e a sociedade no Brasil. Fruto de uma era populista, modificou paulatinamente sua orientação até seu fechamento, em 1968, sendo marcada por uma postura anti-imperialista (defesa dos recursos nacionais, por exemplo) e nacional desenvolvimentista, dando ênfase à defesa da cultura popular e ao papel educativo e político das artes.

Analisando a produção escrita destes dois escritores, nas décadas de 1960 e 1970, foi também possível identificar um alinhamento ideológico e temático entre seus escritos e as ideias desenvolvidas e difundidas pelo Instituto Superior de Estudos Brasileiros (ISEB), criado em 1955 como um instituto oficial e autônomo, mas vinculado ao Ministério da Educação e Cultura. Nele atuaram intelectuais que se dedicaram ao estudo da realidade nacional, propondo um projeto de Brasil que se efetivaria pelo desenvolvimento industrial e capitalista do país, a ser promovido por uma burguesia nacionalista e anti-imperialista, capaz

\footnotetext{
${ }^{17}$ Embora Dias Gomes nunca tenha sido preso, sofreu com as sanções de duas ditaduras: a Ditadura Vargas e a Ditadura Civil Militar. "Dias Gomes foi indiciado a cinco IPMs, entre eles o da Rádio Nacional, o do Partido Comunista e o da Imprensa Comunista" (ROLLEMBERG, 2000, p. 382).

${ }^{18}$ Com a comoção popular provocada pelo suicídio de Vargas, o PCB, que passara todo o mandato democrático contrário ao estadista, alterou seu posicionamento político e engajou-se no apoio ao nacional populismo que tinha em Vargas sua principal referência (PALAMARTCHUK, 2003).
} 
de integrar a nação neste objetivo. Extinto após o golpe de 1964, o instituto deixou sua marca no trabalho de diversos intelectuais que sobreviveram ao regime. Suas ideias estavam em consonância com o posicionamento do PCB e com o de outros núcleos intelectuais de esquerda, contrários à Ditadura civil-militar, posicionados na defesa de uma aliança entre a burguesia e o proletariado, e que viam na democracia burguesa uma etapa necessária para o desenvolvimento da nação (TOLEDO, 1977). Nesta perspectiva, o desenvolvimento econômico e a consciência nacionalista realizariam o projeto de desenvolvimento nacional, conquistando a autonomia e a independência do país em prol da coletividade. A proximidade ideológica entre as produções discursivas de Dias Gomes, de Ferreira Gullar, e as ideias defendidas pelo ISEB, é uma pista importante para entender suas escolhas no processo de rememoração de Getúlio Vargas.

O ex-presidente Vargas consolidou-se como uma referência na História econômica nacional, quando se pensa no processo de modernização do país. O Golpe político de 1930 que conduziu Vargas pela primeira vez à presidência do Brasil - depôs do poder o monopólio de uma oligarquia agrária, cuja administração da economia nacional estava emperrando o processo de industrialização, orientando a economia nacional como uma economia unicamente agrário-exportadora, cujo principal produto de exportação - o café - centralizava os investimentos do Estado em detrimento do desenvolvimento econômico nacional. Somados a isso, os reflexos da Crise de 1929 haviam atingido fortemente a economia brasileira, gerando desemprego e dificuldade financeira não a população. $\mathrm{Na}$ administração econômica do país, Getúlio Vargas buscou aplicar um programa econômico industrial, capitalista, nacionalista e com forte controle estatal, o que favoreceu a modernização do Brasil.

Quando Getúlio Vargas é rememorado no texto dramático Dr. Getúlio, sua vida e sua glória, privilegiando o período democrático em detrimento do período ditatorial e dando ênfase à sua política nacionalista, a rememoração está em consonância com a face da política varguista privilegiada pelo ISEB, que tem Vargas como uma referência positiva de nacionalismo e de industrialização.

Trata-se de um recorte seletivo da trajetória deste sujeito político, desconsiderando que o preço deste desenvolvimento foi a centralização autoritária do poder estatal e da política econômica; o uso da tortura como uma das práticas instituídas pelo aparelho de repressão policial; a instauração de um Estado exceção, sem garantia das liberdades individuais; e o fato de Vargas manter entre seus quadros, sujeitos políticos declaradamente simpáticos ao Nazismo, e em especial à polícia política alemã (GESTAPO), tal qual Filinto Müller, que foi chefe da Delegacia Especial de Segurança Política e Social (DESP), durante o Estado Novo. 
Correlacionando as informações obtidas sobre o ISEB, a RCB, e as estratégias políticas do PCB, na década de 1960, com a narrativa Dr. Getúlio, sua vida e sua glória, notase uma correspondência ideológica e temática. Além de defenderem o passado populista brasileiro como uma experiência positiva de governo, seus discursos tocam em questões comuns quando analisam o cenário político nacional: a exemplo da defesa da democracia, do nacionalismo (exemplificado na campanha pela nacionalização da exploração do petróleo) e do anti-imperialismo.

É importante, também, nos atentar para as continuidades e rupturas que percorreram as disputas políticas nacionais. Os dois partidos políticos criados sob influência de Vargas (PTB e PSD) se aliaram na eleição dos três presidentes que governaram o Brasil após sua morte (Juscelino Kubitschek, Jânio Quadros e João Goulart). Assim, houve o uso político de uma rememoração positiva de Getúlio Vargas, para legitimar a ação destes governos e conquistar a simpatia da população.

Marieta de Morais Ferreira (2006), pesquisadora que investiga como as reconstruções da memória do ex-presidente Getúlio Vargas tiveram projeção nos períodos políticos que sucederam sua morte, demonstra que a memória (rememoração) deste sujeito é objeto de disputa, com grande influência nos rumos políticos do país.

Segundo Ferreira, o período de Ditadura civil-militar foi um contexto em que a memória de Vargas foi tratada abertamente de modo negativo pelo discurso oficial do Estado:

Não é de se espantar que a deposição em março de 1964 de seu principal herdeiro, o presidente João Goulart, e o afastamento da cena política de um grande número de partidários do PTB e do PSD - partidos cuja origem está diretamente ligada a Vargas - tenham proporcionado uma conjuntura negativa para o cultivo de sua memória. Os militares que tomaram o poder em 1964 apresentaram-se como aqueles que iam pôr fim à era Vargas (FERREIRA, 2006, p. 3).

Desse modo, ao rememorar Vargas e exaltar sua política nacional desenvolvimentista e suas ações econômicas protecionistas em contraposição à política econômica de alinhamento com o capitalismo internacional, e de boa vizinhança com os Estados Unidos, mantidos durante a Ditadura civil-militar, Dias Gomes e Ferreira Gullar reelaboraram uma crítica, contra o presente concreto e histórico em que estavam imersos, através da rememoração de um passado supostamente mais justo, cuja continuidade teria sido interrompida, a seu ver, pelas mesmas forças políticas e econômicas que no presente sustentavam a Ditadura civilmilitar. 
É nesta conjuntura que Gomes e Gullar elaboram o texto Dr. Getúlio, sua vida e sua glória, uma homenagem à memória do estadista em contraposição ao discurso do Estado militarizado, mas em consonância com a tradição intelectual de esquerda que lhes era contemporânea.

\section{CONSIDERAÇÕES FINAIS}

Ao analisar um texto dramático, esta pesquisa evitou abordar a produção artística como vestígio de uma temporalidade, mas pensá-la como um meio ativo, capaz de apoiar ou impor resistência a um projeto político; interpretar e propor entendimentos acerca do real; vincular discursos e atuar na Memória social. Nosso interesse não foi verificar o grau de verossimilhança, mas como e porque uma memória de Getúlio Vargas foi apropriada e reelaborada durante a Ditadura civil-militar.

Focamos nossa análise no texto propriamente dito, e no contexto intelectual de sua produção, identificando nos grupos com os quais os escritores dialogavam as possíveis explicações para o caráter da memória de Getúlio Vargas, representado no texto.

Outras pesquisas que se interessam pela obra podem aprofundar esta análise, investigando, por exemplo, a montagem realizada pelo grupo de teatro Opinião, bem como a repercussão de suas apresentações em jornais e outros periódicos da época. As pesquisas da professora Dra. Katia Rodrigues Paranhos e do professor Dr. Igor Sacramento, dão conta de sustentar este debate.

O crítico de teatro Anatol Rosenfeld, que referiu-se a esse texto dizendo que " Dr. Getúlio é sem dúvida, em escala internacional, uma das mais brilhantes peças políticas da atualidade" (ROSENFELD, 1996, p. 79), realizou um importante estudo sobre a construção do herói no Teatro Brasileiro Moderno. Analisando textos de Augusto Boal, Gianfrancesco Guarnieri, Jorge Andrade e Dias Gomes, não aprofundou a análise quanto a construção do herói, na peça citada, de modo que esperamos ter somado contribuições à analise deste aspecto de tão importante obra da dramaturgia brasileira.

Por fim, esperamos ter demonstrado que é importante estarmos atentos aos discursos, às representações, às leituras e explicações, cientes de que o modo como o passado é rememorado, e se faz presente, varia de acordo com o tempo, os interesses e o lugar de onde ele é evocado. Assim, é possível a elaboração de diversas versões de uma mesma história, diversos enquadramentos de uma mesma personagem.

Para acessar o sentido de uma rememoração é importante identificar como esta 
socialmente posicionada, no que está engajada, e o que quer defender os produtores da atualização do acontecido. A determinação histórica não atua como uma sentença objetiva de causa e efeito, mas como um lastro que capacita e possibilita a ação presente; o sujeito histórico pode, partindo de sua materialidade, contestá-la, confrontá-la, e elaborar estratégias de enfrentamento e de resistência a ordem estabelecida.

Ao evidenciar a historicidade e as relações discursivas de uma produção artística, observamos parte dos limites e da potência da experiência das gerações anteriores que se engajaram na resistência e no enfrentamento da exploração imperialista e da Ditadura civilmilitar no Brasil.

Observamos dentre os problemas da construção do herói Getúlio, protagonista do texto aqui analisado, que ao recuperar uma experiência histórica, os escritores silenciaram as contradições dessa personagem, atualizando apenas o que julgaram ser bom para o período em que estavam. O herói é uma simplificação, um arquétipo que elimina as contradições do sujeito histórico, bem como encobre o protagonismo de outras forças políticas possíveis, preterindo-as a um suposto ser extraordinário e insubstituível.

No momento crítico que atualmente vivenciamos, onde estão em disputa projetos de futuro, reinterpretações do passado e o agenciamento da vida e da morte, testemunhamos o avanço de derivações do fascismo, que ganham projeção e espaços políticos decisivos, bem como manifestações que comemoram a Ditadura e pedem o seu retorno.

Diante disso, desejamos que a leitura deste artigo tenha servido para aprofundar a reflexão crítica dos movimentos de resistência e enfrentamento político contrários ao autoritarismo e a exploração humana, e possa embasar o questionamento da atualização de antigos "heróis", para quem sabe, inspirar a produção de novos dispositivos políticos, que renunciem a uma possível repetição da História, seja como tragédia, como drama ou como farsa.

\section{REFERÊNCIAS}

ARISTÓTELES. Poética. Tradução: Eudoro de Souza. In: Coleção Os Pensadores. Volume IV. 1. ed. São Paulo: Abril, 1973.

BLOCH, Marc. Apologia da história, ou o ofício do historiador. Tradução: André Telles. Rio de Janeiro: Jorge Zahar,2001.

BRECHT, Bertolt. Teatro dialético. 1.ed. Rio de Janeiro: Civilização brasileira, 1997. 
CAMPEDELI, Samira. Dias Gomes: seleção de textos, notas, estudos biográficos, histórico e crítico e exercícios. 1.ed. São Paulo: Abril educação, 1982.

COGGIOLA, Osvaldo. Governos militares na América Latina - A era das ditaduras Chile, Argentina e Brasil; luta armada e repressão. Coordenador Jaime Pinsk. Coleção Repensando a História. São Paulo: Ed. Contexto, 2002.

FAUSTO, Boris. Getúlio Vargas o poder e o sorriso. 1.ed. São Paulo: Companhia das Letras, 2006.

FERREIRA, Marieta de Morais. Getúlio Vargas: Uma memória em disputa. Rio de Janeiro: CPDOC/FGV, 2006.16f.

FOUCAULT, Michel. A Ordem do Discurso. Aula inaugural no Collège de France. Pronunciada em 2 de dezembro de 1970. Tradução: Sampaio, L. F. São Paulo: Loyola: 1996. Veja, 2006

O que é um autor. Tradução: CASCAIS, A. F.; CORDEIRO, E. 6.ed. Lisboa: Nova

GOMES, Alfredo de Freitas Dias; GULLAR, Ferreira. Dr. Getúlio, sua vida e sua glória. Rio de Janeiro: Civilização Brasileira, 1968.

GOMES, Alfredo de Freitas Dias. Vargas. In: GOMES, A. F. D. Os espetáculos musicais. Coleção Dias Gomes volume 4. 1 ed. Rio de Janeiro: Bertrand Brasil, 1992.

Apenas um subversivo. $1^{\text {a }}$ Ed. Rio de Janeiro: Bertrand Brasil,1998.

Os caminhos da revolução. Coleção Dias Gomes volume 3. Rio de Janeiro: Bertrand Brasil, 1991.

HALBWACHS, Maurice. A memória coletiva. Tradução: Laurent Léon Shaffter. 4. Ed. São Paulo: Revista dos Tribunais, 1990.

HOBSBAM, Eric J. Era dos extremos: o breve século XX:1914-1991. Tradução: SANTARRITA, M. 2.ed. São Paulo: Companhia das Letras, 1995.

JUNIOR, Gonçalo Silva. País da TV- A História da TV brasileira contada por Gonçalo Junior. 1.ed. São Paulo: Conrad Editora, 2001.

LE GOFF, Jacques. História e memória. Tradução: LEITÃO, B. Coleção Repertórios. Campinas: UNICAMP, 1990.

MOTA, Carlos Guilherme. Ideologia da cultura brasileira (1933-1974). 1. ed. São Paulo: Ática, 1977.

NETO, Lira. Getúlio (1945-1954) - Da volta pela consagração popular ao suicídio. 1.ed. São Paulo: Companhia das Letras, 2014.

ROSENFELD, Anatol. O mito e o herói no moderno teatro Brasileiro. São Paulo: Perspectiva, 1996. 
PALAMARTCHUK, Ana Paula. Os novos bárbaros: escritores e comunismo no Brasil (1928-1948). 2003. 383 p. Tese (Doutorado em História) - Faculdade de Filosofia e Ciências Humanas, Universidade Estadual de Campinas, Campinas, São Paulo, 2003.

PALLOTINE, Renata. Introdução à dramaturgia. Serie Princípios. 1. ed. São Paulo: Ática, 1988.

Dramaturgia. A construção da personagem. 1. ed. São Paulo: Ática, 1989.

PARANHOS, Kátia Rodrigues. Dias Gomes, "Dr. Getúlio" e o teatro musical: engajamento, sonoridades e encenação no Brasil sob a ditadura militar. In: Os palcos da política as políticas do palco. Pitágoras 500. Revista de estudos teatrais instituto de artes da UNICAMP, Campinas, São Paulo, v. 10, p.68-78, 2016.

. Pelas bordas: História e teatro na obra de João das Neves. In. PARANHOS, Kátia Rodrigues (org) História, teatro e política. São Paulo: Boitempo, 2012.

PASCOLATI, Sonia Aparecida Vido. Metateatro: inscrição do espetáculo no texto dramático. In: XI Congresso Internacional da ABRALIC, Tessituras, Interações, Convergências, USP, 2008, São Paulo, $8 \mathrm{p}$. Disponível $\quad$ em: $<$ http://www.abralic.org.br/eventos/cong2008/AnaisOnline/simposios/pdf/023/SONIA_PASCO LATTI.pdf.> Acesso em: 20 jun. 2020.

POLLAK. Michael. Memória, Esquecimento, Silêncio. Tradução: FLAKSMAN, D. R. Estudos Históricos, Rio de Janeiro, vol. 2, n. 3, p. 3-15, 1989.

PRADO, Décio de Almeida. Teatro brasileiro moderno. 2.ed. São Paulo: Perspectiva, 2003.

A personagem no teatro. In: Candido, A. et al. A personagem de ficção. 10.ed. Coleção debates. São Paulo: Perspectiva, 2007. p.81-102.

RIDENTI, Marcelo. Brasilidade Revolucionária. São Paulo: UNESP, 2010.

O fantasma da revolução brasileira. 2. ed. São Paulo: UNESP, 2010.

ROLLEMBERG, Denise. Ditadura, intelectuais e sociedade: O bem-amado de Dias Gomes. In: CASTRO, A. et al.(org) Cultura política, memória e historiografia. Rio de Janeiro: Ed FGV, 2000 p. 382).

SACRAMENTO, Igor Pinto. Nos tempos de Dias Gomes: a trajetória de um intelectual comunista nas tramas comunicacionais. 2012. Tese (Doutorado em Comunicação e Cultura) Escola de Comunicação, Universidade Federal do Rio de Janeiro, Rio de Janeiro.

TOLEDO, Caio Navarro de. ISEB: Fábrica de Ideologias. 1. Ed. São Paulo: Ática, 1977.

VIGOTSKI, Levi S. Psicologia da arte. Tradução: Bezerra, P. 1. Ed. São Paulo: Martins Fontes, 1999. 